\title{
Pre-B-Cell Leukemia Transcription Factor
}

3

National Cancer Institute

\section{Source}

National Cancer Institute. Pre-B-Cell Leukemia Transcription Factor 3. NCI Thesaurus.

Code C30139.

Pre-B-cell leukemia transcription factor 3 (434 aa, $\sim 47 \mathrm{kDa}$ ) is encoded by the human PBX3 gene. This protein plays a role in the activation of gene transcription. 